\title{
DA IMERSÃO À EMERSÃO: NARRATIVA E TRANSITIVIDADE NA RESSIGNIFICAÇÃO DO EU
}

\author{
FROM IMMERSION TO EMERSION: NARRATIVE AND \\ TRANSITIVITY IN THE RESSIGNIFICATION OF THE SELF
}

Thiago Lemes de Oliveira (UFU)

thilemesoli@gmail.com

Tania Regina de Souza Romero (UFLA)

taniaromero@ufla.com

\begin{abstract}
RESUMO: Partindo de uma narrativa autobiográfica, esta pesquisa enfoca e reflete sobre a ressignificação de fatos traumáticos como importante ferramenta para compreender o processo de construção social da identidade. Objetiva-se, portanto, identificar e refletir sobre influências socioculturais, sobre experiências vivenciadas e circunstâncias adversas que foram impostas durante a constituição pessoal de um dos autores e, conforme compreendidas pelo narrador, tendo por foco as pessoas que colaboraram para a superação de tais situações adversas. A abordagem metodológica é de âmbito qualitativo, sendo utilizado o método de investigação autobiográfico, com a interpretação substanciada por análise linguística pela ótica da Gramática Sistêmico-Funcional, especificamente a transitividade. Além disso, a ferramenta teórica adotada auxilia nesse ponto na identificação dos participantes e, consequentemente, nas pessoas implicadas no processo de construção identitária. Como resultado, os autores destacam o papel dos avós maternos e da mãe na construção da identidade do autor-narrador pesquisador, principalmente no processo de ressignificação e reconstrução da identidade ante fatos especialmente sensíveis.
\end{abstract}

PALAVRAS-CHAVE: narrativa autobiográfica; identidade; transitividade.

ABSTRACT: Taking an autobiographical narrative as a starting point, this research focuses and reflects on the resignification of traumatic facts as an important tool to understand the process of social construction of identity. It aims, therefore, to identify and reflect on sociocultural influences, on lived experiences and adverse events imposed during one of the author's personal constitution, and as understood by the narrator, focusing on people who collaborated to overcome such adverse situations. The methodological approach is qualitative, and the method of autobiographical investigation is used, having the interpretation strengthened by linguistic analysis in the perspective of the SystemicFunctional Grammar, more specifically transitivity. In addition, the theoretical tool adopted helps at this point in identifying the participants and, consequently, the people involved in the 
process of identity construction. As a result, the authors highlight the role of the maternal grandparents and the mother of the author-narrator-researcher in his identity construction, mainly in the process of resignification and reconstruction of his identity in face of especially sensible facts.

KEYWORDS: autobiographical narrative; identity; transitivity.

\section{Imergindo no "eu"}

Esta pesquisa apresenta os resultados de investigações desenvolvidas durante o curso de Mestrado Profissional em Educação na Universidade Federal de Lavras no âmbito do projeto de pesquisa IDOLIN ${ }^{1}$. Esclarece-se que esta é uma reflexão sobre a constituição identitária de um dos autores gerada, por meio de uma narrativa autobiográfica do autornarrador deste estudo, como ferramenta para a compreensão do processo de desenvolvimento identitário do autor-narrador. Partimos do pressuposto de que narrar e discutir o próprio percurso, à luz da teoria de identidade (FREITAS; GHEDIN, 2015; CUNHA, 2016), e da Linguística Sistêmico-Funcional (HALLIDAY; MATTHIESSEN, 2004; MARTIN; ROSE, 2005; FUZER; CABRAL, 2014), auxiliam no processo de compreensão e conscientização de si.

Nesse viés, observa-se que o uso das narrativas autobiográficas tem sido instrumento de (auto)conscientização e reflexão, bem como base de investigação acadêmica, desde a década de 1980 nas ciências humanas (ROMERO; LIBERALI; MAGALHÃES, 2003). Conforme frisa Barcelos (2020, p. 29), citando outros estudiosos da área: "a importância das narrativas está relacionada à sua capacidade de nos ajudar a reconhecer e compreender as dimensões emocionais, morais e relacionais do conhecimento do professor". A partir desse pressuposto, esse recurso tem sido amplamente utilizado, por exemplo, na área de formação de professores (CRUZ, 2016; OLIVEIRA, 2017).

Este estudo difere dos tematizados com vistas à conscientização sobre a formação docente ou profissional ao enfocar um trauma físico e psicológico para salientar o desenvolvimento identitário de um dos autores, atualmente educador na área de Língua Brasileira de Sinais - LIBRAS. Ademais, conforme se verá mais adiante, pretende-se evidenciar como criteriosa análise linguística pode desvelar significados que contribuem e

\footnotetext{
${ }^{1}$ Identidade do Docente de Línguas. O projeto é desenvolvido na Universidade Federal de Lavras, sob a coordenação da professora doutora Tania Regina de Souza Romero Visa a discutir e refletir sobre o processo de construção da identidade do docente de línguas materna e adicionais.
} 
aprofundam a ressignificação do sujeito.

Cabe informar ao leitor, a título de contextualização, que a formação inicial do autornarrador desta pesquisa como tradutor e intérprete de Libras se deu informalmente pelo desenvolvimento de trabalho voluntário, social e religioso, no contato direto com o indivíduo alheio à sociedade, sem voz e sem visibilidade. Especificamente, dedicou-se ao acolhimento e à educação de $\operatorname{Surdos}^{2}$ e de imigrantes (Surdos e ouvintes) em situação de exclusão social. Posteriormente, formou-se em Pedagogia e, atualmente, dedica-se ao preparo de educadores e/ou futuros educadores.

À vista disso, as investigações desse autor-narrador centram-se nas seguintes perguntas de pesquisa: 1. Quais foram as principais pessoas mencionadas durante os momentos de trauma e ressignificação em sua autobiografia e qual é a participação delas em sua construção identitária? 2. Quais significados são construídos sobre elas e quais escolhas linguísticas constituem as construções desses significados?

Considerando tais questionamentos, e com o intuito de que esses sejam os norteadores para compreender a construção da identidade e os significados atribuídos a ela, esta produção apresenta, inicialmente, uma contextualização com o tópico "Como tudo começou", que exibe a constituição pessoal, familiar e social do sujeito. O segundo tópico, "Conhecendo sobre identidades", aborda as teorias sobre a construção da identidade, vinculando esse construto à escrita da narrativa autobiográfica como ferramenta para compreensão dessa identidade. Em seguida, "Decifrando o eu: uma teoria de análise" define as abordagens metodológicas em que a pesquisa se ancora, bem como, sobre quais foram os dados escolhidos para o seu desenvolvimento. A partir disso, a "Narrativa sob análise" constitui-se de uma trama que, em sua tecitura, apresenta a análise dos dados com base nos conceitos resenhados e referendados pela análise linguística, segundo instrumento da Linguística Sistêmico-Funcional (LSF). Culminamos, então, para a conclusão intitulada "Concluindo: o eu refazendo-se", na qual refletimos sobre as possíveis contribuições desta pesquisa para os autores e para a comunidade acadêmica.

\section{Como tudo começou}

Esta seção visa a contextualizar um trecho do percurso de formação identitária do

\footnotetext{
${ }^{2}$ Refletindo sobre as muitas pesquisas acerca da questão terminológica para identificar o sujeito com deficiência auditiva, optamos pelo uso do termo Surdo (com S maiúsculo) para designar o indivíduo pertencente a um grupo linguístico e cultural, que faz uso da Língua de Sinais como a primeira língua de interação social e que é diferente da comunidade de pessoas ouvintes. (GESSER, 2009; SACKS, 2010)
} 
autor-narrador. É, portanto, composta por excertos de sua autobiografia, apresentados em itálico entre aspas, seguidos de informações necessárias ao entendimento do leitor. Cabe esclarecer que a autobiografia, de onde os excertos foram extraídos, foi produzida como um produto avaliativo da disciplina "Linguagem e identidade docente", ofertada no primeiro semestre do mestrado profissional em educação, e que, a partir dela, se desenvolveu a pesquisa aqui partilhada. Por isso, para fins de identificação e compreensão, justifica-se a escrita de alguns trechos em primeira pessoa, uma vez que tais trechos, até este momento, não haviam sido publicados.

"Nasci filho único de um casal indouto, de classe média baixa, oriundos do interior de Minas Gerais, sendo esses filhos de pais sem formação escolar, descendentes de imigrantes e trabalhadores rurais. Por esta constituição familiar, sempre ouvi, desde a mais tenra infância, minha mãe dizer: 'Você é pobre, então não pode ser bom, precisa se esforçar pra ser o melhor!'”. Esse ensinamento regeu minha vida quase como um mantra, de forma que, ao longo da vida, sempre me dediquei a ser o melhor: o melhor amigo, o melhor filho, o melhor aluno, o melhor profissional.

Assim, pensando a construção desse "eu" e buscando a compreensão de como se deu essa construção, o autor-narrador iniciou a escrita de sua autobiografia como membro participante do projeto de pesquisa IDOLIN. Escrever essa autobiografia com lacunas para autopreservação, segundo ele, seria o mesmo que escrever uma mentira. Ressaltou ainda que não foi um processo fácil, muito menos prazeroso; entretanto, necessário. Quando reviramos o passado, em alguns momentos, conforme reflete na narrativa, para ele é como se estivéssemos "cutucando um vespeiro que pensávamos estar adormecido, e logo descobrimos que não estava. Ao mesmo tempo, percebemos que esse passado também pode ser comparado a uma planta senescente que permanece adormecida por um tempo, mas que, ao encontrar condições favoráveis, floresce" e se ressignifica, fazendo renascer um ser vivo diferente, consciente de seu vigor e potencial. Assim, em sintonia com os estudos que sustentam o enfoque (auto)biográfico, o resgate da memória, fatos, histórias e pessoas para a escrita autobiográfica, constitui-se um caminho, muitas vezes, sinuoso, que converge para o encontro de si mesmo.

"Quando criança, sem entender com o que eu lutava calado, minha avó já me dizia: 'Quando se chega ao fundo do poço, o único caminho que resta é subir!'. Minha avó, constantemente, me dizia isso como um lembrete a ela mesma”, que também se encontrava em situação de desespero, como se esclarecerá adiante. "Mal sabia ela que eu também havia sido jogado nesse poço, pela mesma pessoa que um dia foi seu carcereiro”. 
"Na infância, fui vítima de pedofilia, sendo meu avô materno o meu agressor. $O$ primeiro ataque de que me recordo aconteceu aos seis anos de idade, e durou até os onze, quando, finalmente, aprendi a me defender sozinho e a dar um basta. Por muitos anos, permaneci calado, culpado, coagido e me sentindo inferiorizado. Somente após o falecimento daquele que era meu agressor, e de ter relatado a agressão que sofri a minha família, aos dezenove anos, foi que consegui, enfim, sair completamente daquele poço, mencionado anteriormente, onde havia sido atirado".

Mais tarde, durante o processo retrospectivo de memórias e fatos para compor esta pesquisa, bem como para realizar sua análise, o autor-narrador compreendeu que, embora tivesse sido jogado no fundo do poço, assim como a fala de sua avó, aos poucos, ele já escalava para sair dali. Seu poço era silencioso, pois haviam calado sua voz e, para encontrála, buscou, enquanto educador, desenvolver um ensino que pudesse auxiliar os menos favorecidos.

Dessa forma, discorremos a seguir sobre como se deu a construção das identidades do autor-narrador pelos outros e com os outros, uma vez que, conforme escreveu Vygotsky (1998a, p. 75), “as funções no desenvolvimento da criança ocorrem em dois níveis: primeiro, no nível social e depois, no nível individual; primeiro, entre pessoas e depois, no interior da criança". Em nosso caso, essa construção em primeira instância no âmbito social ocorreu, principalmente, pelas experiências vivenciadas no contexto familiar e escolar. Posteriormente, conforme analisa o narrador, foram interiorizadas para que pudessem ser utilizadas a seu favor, conscientemente ou não. Pondera-se, então, sobre a importância da narrativa autobiográfica e sua análise como ferramenta para o (auto)conhecimento e conscientização da identidade (PEREIRA, 2010; FREITAS; GHEDIN, 2015; CUNHA, 2016; REICHMANN; ROMERO, 2018), e de como como esse processo de imersão contribui para a emersão da pessoa que hoje se configura.

\section{Conhecendo sobre identidade}

Uma identidade não é construída pela fragmentação dos campos que compõem nossa vida, mas pelo significado que construímos sobre episódios evidenciados. Nessa conjectura, compreende-se que a identidade de um sujeito é plural, social, desenvolvida a partir dos significados que confere a sua história e aos diversos contextos em que está inserido. Sendo plural e considerando-se que o sujeito se ressignifica ao se dar conta de tais aspectos, Cunha (2016) pondera a necessidade de uma reflexão a partir da narrativa, ao mencionar que: 
Lembrar-se de si, (re)memorar seu passado, refletir sobre si como resultado de um processo complexo de influências e escolhas, narrar e escrever sobre si, é um exercício que se apresenta como um princípio organizador que resulta em uma representação que o sujeito faz de si. (CUNHA, 2016, p. 96-97)

Narrar a história possibilitou ao autor-narrador lançar um olhar amplificado, direcionado para as experiências que vivenciou e para os sentidos que atribuiu a cada uma delas no convívio social com o outro e, principalmente, para o atendimento do outro, evidenciando, assim, a relevância da narrativa autobiográfica para compreender a formação de sua identidade.

Nesse sentido, conforme interpretamos, metaforicamente, narrar e escrever uma autobiografia é um investimento pessoal, que pode ser comparado ao trabalho de curadoria para a composição de uma exposição permanente do museu de si. Ao apreciar o produto, a exposição desse museu, com releituras e atribuição de significados, percebe-se como a narrativa, seja oral, seja escrita, é capaz de conduzir nosso entendimento rumo ao autoconhecimento. É por isso que, para Schafer (1981), o desenvolvimento pessoal pode ser caracterizado pela mudança nos questionamentos sobre o que é urgente ou essencial se responder. Como um projeto de desenvolvimento pessoal, a análise pessoal, especialmente quando teoricamente embasada, muda o curso das questões condutoras.

Rememorar a participação de pessoas que desempenharam papéis marcantes na própria vida, a partir da escrita autobiográfica, transforma o sujeito narrador em dono de sua história, permitindo-o, assim, adentrar a um mundo de caça a tesouros que nunca estiveram escondidos. Para Bruner (1991),

um narrador, do aqui e agora, assume, ele ou ela mesma a tarefa de descrever o progresso do protagonista do lá e então, a quem, por acaso, compartilha seu nome. Ele deve, por convenção, trazer o protagonista do passado para o presente de tal maneira que o protagonista e o narrador acabem se fundindo e se tornem uma pessoa com uma consciência compartilhada. Agora, a fim de trazer um protagonista do lá e então até o ponto em que o protagonista original se torna o narrador atual, é necessária uma teoria de crescimento ou, pelo menos, de transformação. (BRUNER, 1991. p.69, tradução nossa) $)^{3}$

É possível inferir, então, que a fusão do protagonista ao narrador equivale à materialização da compreensão de si, naquele presente, a partir dos fatos escolhidos para entender o "eu".

\footnotetext{
${ }^{3}$ No original: A narrator, in the here and now, takes upon himself or herself the task of describing the progress of a protagonist in the there and then, one who happens to share his name. He must by convention bring that protagonist from the past into the present in such a way that the protagonist and the narrator eventually fuse and become one person with a shared consciousness. Now, in order to bring a protagonist from the there and then to the point where the original protagonist becomes the present narrator, one needs a theory of growth or at least of transformation.
} 
Portanto, conceitos de narrativa autobiográfica e identidade se entrelaçam na trama desta pesquisa, visando compor uma tecitura que possa favorecer a compreensão, construção e apropriação da identidade.

\section{Decifrando o "eu”: uma teoria de análise}

Para elucidar a análise deste estudo, cabe observar que se trata de uma pesquisa qualitativa descritiva e explicativa, que visa justificar como eventos e fenômenos durante a vida do sujeito/autor contribuíram e ainda contribuem para sua (re)construção identitária. Sendo uma pesquisa descritiva, ela é também retrospectiva pelo seu plano de ação, conforme fundamenta Flick (2009).

O estudo ancora-se, ainda, na abordagem biográfica, pois compreende-se que, ao narrar sobre si, o sujeito estudado busca significados pertinentes para suas vivências e aprendizagens, valorizando todo o seu percurso durante a construção de sua identidade. Nesse sentido, "o método biográfico facilita o desenvolvimento de uma sociologia holística da formação, mais adequada à especificidade de cada indivíduo" (FINGER, 2010, p. 22).

O recorte dos dados e a seleção de excertos para discussão e análise orientou-se pelas perguntas de pesquisa, especificadas na introdução desse artigo, sobre quais foram as principais pessoas mencionadas durante os momentos de trauma e de ressignificação do autornarrador em sua autobiografia, qual a participação delas em sua construção identitária, quais significados são construídos sobre elas e quais escolhas linguísticas constituem as construções desses significados.

Foram, então, selecionados alguns excertos da narrativa em que o autor-narrador relatou os momentos decisivos para a constituição de suas identidades. Tais fragmentos, escolhidos por estarem diretamente relacionados ao abuso sofrido, foram submetidos a uma análise linguística segundo a Metafunção Experiencial da Gramática Sistêmico-Funcional (GSF) hallidayana, sobre a qual discorremos a seguir.

As ferramentas disponibilizadas pela Gramática Sistêmico-Funcional (GSF) visam oferecer um aprofundamento na compreensão dos significados construídos pela e na linguagem (HALLIDAY; MATTHIESSEN, 2004). Assim, a GSF, como ferramenta de análise linguística para a compreensão de textos orais e escritos, é especialmente adequada por considerar que as escolhas discursivas feitas pelos participantes durante uma interação apresentam mais do que apenas normas linguísticas e regras gramaticais, pois incluem intencionalidade e funcionalidade. 
Visando possibilitar a compreensão dos significados construídos e os propósitos relacionados aos usos da língua, ou seja, seus componentes funcionais fundamentais (FUZER; CABRAL, 2014; NEVES, 1997), Halliday (1994) estabeleceu três metafunções: a experiencial, que desvela como o falante ou escritor vê o mundo material ou interior, a interpessoal, que enfoca relações interpessoais, e a textual, que atenta para a organização da mensagem.

Para fazer a análise dos excertos selecionados da autobiografia, apoiamo-nos especificamente no Sistema de Transitividade da Metafunção Experiencial. Essa metafunção é especialmente pertinente para o estudo aqui proposto por revelar a percepção da pessoa diante do mundo e que, basicamente, rege suas escolhas e argumentos (MARTIN; ROSE, 2005).

Compõem esse sistema os processos, que são ações representadas por verbos ou núcleos verbais, os participantes, que podem ser pessoas, animais, entidades ou objetos, e as circunstâncias, realizadas tipicamente em grupos adverbiais para expressar tempo, lugar, intensidade etc.

Sendo essa metafunção parte de uma abordagem semântico-funcional que se preocupa em compreender os sentidos e significados produzidos pela linguagem, o entendimento dos seus processos se faz necessário. São eles: (1) Material: representado por verbos que exprimem o sentido de "fazer", ou seja, destacam as ações físicas, concretas. Essas podem ser classificadas em dois subtipos: criativas e transformativas. Quando o processo material é de ordem criativa, o participante existe em função do desenvolvimento do processo, enquanto no processo transformativo, ocorre a mudança ou transformação de um processo já existente no participante. A denominação dos principais participantes são Ator e Meta; (2) Mental: processos ligados ao sentido de "sentir" e "pensar", em que os participantes são o Experienciador e o Fenômeno; (3) Comportamental: processo manifesto por atividades fisiológicas ou psicológicas. É um intermediário entre os processos material e mental, e o participante nesse processo é o Comportante; (4) Verbal: processo ligado ao sentido de “dizer”, para o qual os participantes podem ser o Dizente ou o Receptor, Verbiagem ou Alvo; (5) Existencial: processo ligado ao sentido de "existir", que tem o Comportante como participante; (6) Relacional: processo que exprime o sentido de "ser" ou "ter", sendo os participantes o Portador, Atributo, Característica ou Valor (SILVA; SILVA; BORBA, 2016).

À luz desses enfoques teóricos de análise, e no intuito de responder à segunda pergunta de pesquisa deste artigo, categorizamos a análise da autobiografia em três fases: a) Infância e adolescência, b) Vida adulta e c) Desenvolvimento da vida Profissional.

Seguem as discussões e reflexões de excertos da autobiografia diretamente Organon, Porto Alegre, v. 36, n. 71, p. 35-50, jan./jun. 2021. 
relacionados aos propósitos de investigação em cada uma dessas fases.

\section{Narrativa sob análise: discussão dos dados}

Os excertos selecionados para análise foram categorizados da seguinte forma: (1) Infância e Adolescência: nesta fase, talvez a mais difícil de ter sido escrita, o autor-narrador relatou o abuso sexual que sofreu na infância, bem como os eventos e pessoas que o ajudaram a conviver e a ressignificar esse trauma, sem permitir que ele anulasse suas potencialidades. Visto que os processos e participantes desempenham funções distintas na oração, em todos os excertos analisados a seguir, optamos pelos processos destacados em itálico e negrito, e os participantes, em itálico, negrito e sublinhado. Pode-se perceber, nos excertos abaixo, o aparecimento das pessoas que contribuíram de forma significativa para isso:

\section{Excerto 1- Infância e adolescência:}

Ainda criança sem saber com o que eu lutava calado, minha avó já me dizia: "Quando se chega ao fundo do poço, o único caminho que resta é subir!" Minha avó, constantemente, me dizia isso como um lembrete a ela mesma, que havia sido mantida presa ali durante muito tempo.

Nessa época sempre ouvi minha mãe dizer: "Você é pobre, então não pode ser bom, precisa se esforçar pra ser o melhor!’ [...]

Nessa fase, o narrador é influenciado por duas participantes: a mãe e a avó materna. Embora elas tenham aparecido apenas 3 vezes na autobiografia (avó: 2 vezes, mãe: 1 vez), consideramos essas menções de grande relevância, uma vez que as palavras delas aparecem em destaque logo no início da autobiografia e parecem dar uma direção para a vida do autobiografado.

Os processos relacionados a essas participantes, destacados em negrito, nas orações: minha avó já me dizia/ Minha avó, constantemente, me dizia/ Nessa época sempre ouvi minha mãe dizer; foram de ordem verbal, por isso as participantes aqui são denominadas Dizentes ${ }^{4}$, ao passo que o participante $e u$ é denominado Receptor.

As orações "Quando se chega ao fundo do poço, o único caminho que resta é subir/ Você é pobre, então não pode ser bom, precisa se esforçar pra ser o melhor!", presentes nas Citações das Dizentes, são de ordem relacional sendo que, na primeira, verifica-se a ocorrência de um processo relacional identificativo, enquanto que, na segunda, há uma clara

\footnotetext{
${ }^{4}$ Para identificação com a teoria da GSF, os participantes de cada processo serão escritos com letra maiúscula, conforme esquema de representação de Cabral e Fuzer (2014, p. 45) a partir de Halliday e Matthiessen (2004).
} 
evidência de processos relacionais atributivos, em que ao Portador "eu" são designados Atributos como pobre, bom e melhor. Nas orações "com o que eu lutava calado/ que havia sido mantida presa ali durante muito tempo", os processos materiais são transformativos, sendo o participante, na primeira oração, um Ator que pratica a ação, e, na segunda, é o Meta que recebe o impacto da ação. Vale ressaltar ao leitor que tais processos atribuídos aos participantes, embora pareçam processos mentais, são entendidos como materiais transformativos, uma vez que as palavras "lutava" e "presa", mencionadas no trecho, consistem em agressões e abusos de ordem física. Por fim, nas orações, "Ainda criança sem saber/ precisa se esforçar”, os processos mentais são de ordem cognitiva e emotiva, e, por serem esses processos tipicamente humanos, o participante é denominado Experienciador. Com isso, a análise desse primeiro excerto mostra que os processos verbais revelam uma interposição de ensinamentos que regeram e direcionaram a vida do sujeito, tanto pessoal como profissionalmente. Nessa perspectiva, as ocorrências dos processos relacionais "é" e "ser" instauraram a percepção de uma realidade e expectativas futuras. Já o estímulo para a ação transformativa é representado pelos processos material (lutar) e mental (saber, esforçar).

A segunda fase (2) Vida adulta, é marcada pela compreensão do que aconteceu com o autor-narrador, ao conseguir, enfim, compartilhar o trauma que sofreu com sua família, não permitindo mais que as lembranças daquele abuso o controlasse negativamente, como se pode notar pela escolha linguística dos processos em destaque e na análise do excerto a seguir:

\section{Excerto 2 - Vida adulta:}

Na infância fui vítima de pedofilia, tendo sido meu avô materno meu agressor. O primeiro ataque de que $\underline{\text { me }}$ recordo aconteceu aos seis anos de idade, e durou até os onze, quando finalmente aprendi a $\underline{\text { me }}$ defender sozinho e dar um basta. Por muitos anos,

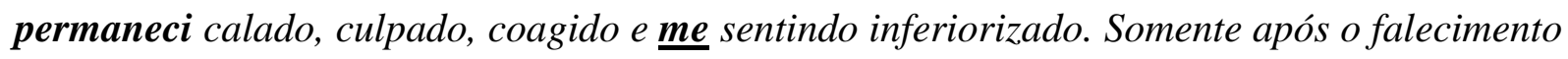
$\underline{\text { daquele }}$ que era meu agressor, e de ter relatado a agressão que sofri a minha família, foi que consegui, enfim, sair completamente daquele poço, outrora mencionado, onde havia sido atirado; a essa altura, já tinha dezenove anos.

As escolhas linguísticas utilizadas para narrar esse excerto revelou principalmente duas pessoas: eu e avô. Minha família é outro grupo de pessoas que figuram como participante, mas, no relato, aparece como somente ouvindo seu relato, não agindo, por isso não o destacamos na análise. Então, para a pessoa do "eu", nas orações "quando finalmente aprendi me defender sozinho e dar um basta/ foi que consegui/ onde havia sido atirado", os processos são de ordem material transformativa e mental cognitiva. Na primeira oração, o participante aparece como Experienciador, que exerce a ação consciente ligada ao processo 
mental do aprender, é também como o Ator, já que pratica a ação dos processos materiais defender e dar. Já na segunda oração, de ordem mental, ele é novamente o Experienciador, ao agir pelo processo consciente conseguir, e, na terceira, novamente de ordem material, ele é o Meta, que sofre a ação do processo atirado. Nas orações "Na infância fui vítima de pedofilia, tendo sido meu avô materno meu agressor/ Por muitos anos, permaneci calado, culpado, coagido e me sentindo inferiorizado”, o participante é denominado Identificado, na primeira oração, representado pelos processos relacionais identificativos fui e sido e pelos identificadores vítima e agressor; e Portador na segunda, pelo processo permaneci e os Atributos calado, culpado, coagido, inferiorizado. Por fim, na oração "e de ter relatado a agressão que sofri a minha família", o participante "eu" é o Dizente, que empreende o processo relatado ao participante alvo "minha família". Portanto, conforme interpretamos, tais atribuições parecem sugerir que o participante "eu" empreendeu ação mental e física, de forma árdua, para a ressignificação do trauma sofrido. Isso fica ainda mais evidente pela escolha das circunstâncias "finalmente" e "a ponto de dar um basta".

Para a pessoa "avô", nas orações "tendo sido meu avô materno meu agressor/ Somente após o falecimento daquele que era meu agressor", os processos escolhidos foram relacionais identificativo e atributivo. Na primeira oração, o participante é Identificado em "meu avô materno", e, ao mesmo tempo, Atributo, pelo uso de "agressor", ambos ligados ao processo relacional sido. Nota-se, ainda, que essa pessoa, ao ser mencionada, é identificada não mais com um termo que aponte vínculo familiar, de proximidade, mas com o termo agressor (meu agressor / daquele que era meu agressor), que insere uma característica de perversa ação material, uma vez que o atributivo deriva do processo material transformativo de contato agredir. $\mathrm{O}$ distanciamento de laços afetivos que vai construindo linguisticamente esse personagem pode ser observado de forma mais contundente no final do excerto, quando se faz uso da voz passiva - havia sido atirado. Com o uso da voz passiva, se dá ênfase à ação, ocultando o participante que a realizou. Ocultar o participante pode ser interpretado como uma forma de tentar apagar o participante da vida do protagonista para si mesmo enquanto narrador.

A terceira e última fase (3) Desenvolvimento da Vida Profissional revelou como suas escolhas profissionais sempre estiveram voltadas para o acolhimento de pessoas em situação de exclusão e/ou vulnerabilidade social que, assim como ele, precisavam superar ou aprender a conviver com os traumas que lhes foram impostos: crianças vítimas de abuso, pessoas com deficiência, em situação de rua, idosos em situação de abandono e os Surdos. Esses últimos, os Surdos, que exigiram sua atenção durante os anos escolares, foram aqueles que fizeram 
emergir o profissional que se tornou, conforme evidenciam os excertos abaixo:

\section{Excerto 3 - Desenvolvimento da vida profissional}

Assim, ao longo dos anos, tive de me reinventar e aprender, pela necessidade, a ser vários educadores num só, para que pudesse dar voz àqueles que, assim como eu, tiveram suas vozes caladas.

Nessa fase final, os processos reinventar e aprender, de ordem mental cognitiva e emotiva, desvelam a ação de esforço do Experienciador "eu" para sair do poço metafórico onde havia sido jogado. O processo mental emotivo, conforme interpretamos, é o processo de ordem mental impulsionado por alguma emoção, nesse caso evidenciado pelo interesse empático do participante em função do outro. Coerentemente, aqui, o participante "eu" é um Ator que dá voz aos participantes denominados Beneficiários, "que tiveram suas vozes caladas". Ou seja, o próprio Ator age para que a transformação criativa ocorra. Assim, a voz era dada ao outro por intermédio dele.

Após a realização dessas análises, foi possível responder às duas perguntas de pesquisa deste artigo, com a identificação das pessoas relevantes mencionadas na narrativa e das escolhas linguísticas que constituíram as construções de significados na produção escrita e atribuíram sentido a elas. As tabelas a seguir mensuram a ocorrência dos processos relacionados a cada pessoa mencionada na autobiografia. Na primeira tabela, apresentamos os processos atribuídos ao autor-narrador “eu”, enquanto participante, em cada uma das fases resenhadas anteriormente. Na segunda tabela, por sua vez, apresentamos os processos atribuídos a cada uma das pessoas participantes de cada fase.

\begin{tabular}{|c|c|c|c|}
\hline Fases da vida & $\begin{array}{c}\text { Infância e } \\
\text { adolescência }\end{array}$ & Vida adulta & $\begin{array}{c}\text { Desenvolvimento } \\
\text { da vida } \\
\text { profissional }\end{array}$ \\
\hline Comportamental & & & \\
\hline Existencial & & 4 & 1 \\
\hline Material & 2 & 2 & 2 \\
\hline Mental & 2 & 4 & 1 \\
\hline Relacional & & 1 & \\
\hline Verbal & & & \\
\hline
\end{tabular}

Tabela 1 - Fases e processos do participante "eu"

Fonte: Elaborada pelos autores 


\begin{tabular}{|c|c|c|c|}
\hline Processos & Mãe & Avó & Avô \\
\hline Comportamental & & & \\
\hline Existencial & & & \\
\hline Material & 1 & 2 & \\
\hline Mental & & & \\
\hline Relacional & 3 & 2 & 2 \\
\hline Verbal & 1 & 2 & \\
\hline
\end{tabular}

Tabela 2: Processos relacionados aos outros participantes

Fonte: Elaborada pelos autores

Comentando os resultados apresentados nas tabelas 1 e 2, é possível notar que: (1) os processos atribuídos ao autor-narrador "eu" enquanto participante foram, em sua maioria, de ordem material, mental e relacional, ligados diretamente aos processos: material transformativo, mental cognitivo/afetivo e relacional atributivo, indicando a necessidade de ação transformadora constante. Pode-se interpretar as escolhas linguísticas como indicativas de como um indivíduo ativo diante do problema, alguém que não admite a condição passiva como enfrentamento para adversidades. (2) Os processos atribuídos à avó e à mãe como participante foram relacionados aos processos material criativo, relacional identificativo/atributivo e verbal ligados aos significados de "fazer", "ter e simbolizar" e "sentir", evidenciando um equilíbrio entre a ação e o afeto. (3) Os processos atribuídos ao avô como participante foram todos representados pelo processo relacional identificativo/atributivo escritos na passiva, podendo ser interpretados como um esforço inconsciente de obliterar a relação desse participante em sua vida. (4) As pessoas que aparecem menos como participantes - mãe, avó-, foram, contrariamente à expectativa, as que pareceram ter influenciado mais decisivamente a construção identitária do narrador, sendo propulsores de suas escolhas profissionais.

Dessa forma, retomando as perguntas que nortearam esta pesquisa, concluímos que as pessoas mencionadas na autobiografia durante os momentos de trauma e ressignificação, contribuíram diretamente para a construção da identidade pessoal do narrador. Sem a participação daquelas pessoas - avó, mãe - que ocuparam o papel de guias-mentores em sua vida, provavelmente não haveria a emersão da criança violentada. A compreensão da narrativa, tornada possível pelo embasamento teórico e linguístico discutido, permite tecer as reflexões finais que se seguem, na perspectiva do narrador-pesquisador. 


\section{Concluindo: o "eu” refazendo-se}

Respondendo às perguntas de pesquisa que nortearam este trabalho (quais foram as principais pessoas mencionadas durante os momentos de trauma e ressignificação da autobiografia do autor-narrador e qual é a participação delas em sua construção identitária), compreendemos que o trauma causado pelas agressões sexuais infligidas a ele durante a infância pelo avô, criou, no autor-narrador da pesquisa, de forma inconsciente, uma necessidade constante de superação, em resposta às vozes ecoadas da avó (Quando se chega ao fundo do poço, o único caminho que resta é subir!) e da mãe (Você precisa se esforçar pra ser o melhor.).

Nessa direção, quanto aos significados construídos sobre as pessoas mencionadas e quais escolhas linguísticas constituem as construções desses significados, percebemos ainda que, pautados pelos conceitos de identidade, à luz do suporte teórico-metodológico e análise linguística calcada na linguística sistêmico-funcional, permitiu-nos ter indícios de como são construídas as identidades e como essas ressignificam-se a partir do contato com outras identidades, outros sujeitos. Reafirma-se, portanto, a relevância da conscientização pelo conhecimento de si e do outro, como propõe o método autobiográfico. Embora esta pesquisa limite-se a investigar um aspecto da construção de uma única identidade, esse trabalho, ao mesmo tempo árduo e prazeroso, pode constituir-se um estímulo para que outros possam ressignificar suas identidades pessoais, imergindo em suas vivências para a emersão de outras identidades futuras.

Consideramos, finalmente, que, mesmo que as discussões sobre identidade, em suas diversas vertentes, estejam bem consolidadas no cenário acadêmico atual, há ainda um vasto campo de investigação da construção identitária em função de traumas como o relatado.

\section{REFERÊNCIAS}

BARCELOS, Ana Maria Ferreira. Compreendendo a Pesquisa (de) Narrativa. In: GOMES JÚNIOR, Ronaldo Corrêa (Org.). Pesquisa Narrativa: histórias sobre ensinar e aprender línguas. São Paulo: Pimenta Cultural, 2020. p. 19-41.

BRUNER, Jerome. Self-making and world-making. The Journal of Aesthetic Education, Illinois, v. 25, n. 1, p. 67-78, 1991. 
CRUZ, Nubia da Silva. Desenvolvimento profissional docente: formação e inserção profissional das egressas do curso de Letras Língua Espanhola- Uneb campus I. 2016. 197 f. Dissertação (Mestrado em Educação e Contemporaneidade) - Universidade Estadual da Bahia, Salvador, 2016.

CUNHA, Jorge Luiz da. Aprendizagem histórica: narrativas autobiográficas como dispositivo de formação. Educar em revista, Curitiba, n. 60, p. 93-105. abr./jun. 2016. DOI: htpps://doi.org/10.1590/0104-4060.46025

FINGER, Matthias. O método (auto)biográfico e a formação. In: NÓVOA, António; FINGER, Matthias. O método (auto)biográfico e a formação. São Paulo: Paulus, 2010. p. 1929.

FLICK, Uwe. Introdução à pesquisa qualitativa. 3. ed. Porto Alegre: Artmed, 2009.

FREITAS, Liliane Miranda; GHEDIN, Evandro Luiz. Narrativas e formação: origens, significados e usos na pesquisa-formação de professores. Revista Contemporânea de Educação, Rio de Janeiro, v. 10, n. 19, p. 111-131, 2015. DOI:

https://doi.org/10.20500/rce.v10i19.1929

FUZER, Cristiane; CABRAL, Sara Regina Scotta. Introdução à Gramática SistêmicoFuncional em Língua Portuguesa. v. 1. Campinas: Mercado de Letras, 2014.

GESSER, Audrei. LIBRAS? Que língua é essa? Crenças e preconceitos em torno da língua de sinais e da realidade surda. São Paulo: Parábola, 2009.

HALLIDAY, Michael Alexander Kirkwood; MATTHIESSEN, Cristhian Mathias Ingemar. An introduction to functional grammar. 2nd ed. Londres: Arnold, 1994.

HALLIDAY, Michael Alexander Kirkwood; MATTHIESSEN, Cristhian Mathias Ingemar. An introduction to functional grammar. 3rd ed. Londres: Arnold, 2004.

MARTIN, James Robert; ROSE, David. Working with discourse. Meaning Beyond the Clause. London: Continuum, 2005.

NEVES, Maria Helena de Moura. A gramática funcional. São Paulo: Martins Fontes, 1997.

OLIVEIRA, Gabriel Silva de. Conhecimento prático profissional e prático pessoal: experiencias que vivi/vivo são as histórias que me constituem professor. 2017. $105 \mathrm{f}$. Dissertação (Mestrado em Estudos Linguísticos) - Universidade Federal de Uberlândia, Uberlândia, 2017.

PEREIRA, Marcos Vilela. Sobre histórias de vida e autoformação: um enfoque ético e estético. In: Maria Helena Menna Barreto, ABRAHÃO, (Org.). (Auto)biografia e formação humana. Porto Alegre: EDIPUCRS, 2010. p. 123-138.

REICHMANN, Carla Lynn; ROMERO, Tania Regina de Souza. Language's teachers narratives and professional self-making. Delta, São Paulo, v. 35, n.3. p. 1-25, out/nov.2018

ROMERO, Tania Regina de Souza; LIBERALI, F. C.; MAGALHÃES, Maria Cecília 
Camargo. Autobiografia, Diário e Sessão Reflexiva: Atividades na Formação CríticoReflexiva de Professores. In: BARBARA, Leila; RAMOS, Rosinda de Castro Guerra (Orgs.). Reflexão e ações no ensino-aprendizagem de línguas. v. 1. Campinas: Mercado de Letras, 2003. p. 07-367.

SACKS, Oliver. Vendo vozes: uma viagem ao mundo dos surdos. São Paulo: Companhia das letras, 2010.

SCHAFER, Roy. Narration in the Psychoanalytic Dialogue, In: MITCHELL, W. J. T. (Ed.). On Narrative. Chicago: University of Chicago Press, 1981.

SILVA, Wagner Rodrigues; SILVA, Kellen Lucy Santos; BORBA, Lucieny de Castro. Construção da Reflexão na Escrita Acadêmica por Professores em Formação. Revista Brasileira de Linguística Aplicada. Belo Horizonte, v. 16, n. 2, p. 227-308, 2016.

VYGOTSKY, Lev Semionovich. A formação social da mente. São Paulo: Martins Fontes, 1998a.

VYGOTSKY, Lev Semionovich. O desenvolvimento psicológico na infância. São Paulo: Martins Fontes, 1998b. 